The Labore Journal of Economics

$10: 1$ (Summer 2005) pp. 15-32

\title{
Child Labor's Link with Literacy and Poverty in Pakistan
}

\author{
Imran Ashraf Toor
}

\begin{abstract}
In developing countries, children have long been largely ignored in public policy-making and the development of program strategies for improving their welfare. The complex issue of child labor is a developmental issue worth investigating. The notion that children are being exploited and forced into labor, while not receiving education crucial to development, concerns many people. This study focuses on child labor in Pakistan with two main objectives. We first estimate the prevalence of child labor in the 100 districts of Pakistan and then examine the hypothesis that child labor is significantly higher in districts that have a higher incidence of poverty and lower level of educational attainment. The results show that child labor has a negative relationship with the literacy rate both 10-14 year age and 15 years and above. There is a negative but insignificant relationship with per capita income and Deprivation Index in the case of male child labor. The study proved that literacy rate and per capita income has influenced negatively on female child labor.
\end{abstract}

\section{Introduction}

In developing countries, children have long been largely ignored in public policy-making and the development of program strategies for improving their welfare. However, this situation is beginning to change; Governments as well as international development agencies have started increasingly to focus attention on the welfare of children. The World Summit for Children held in 1990 epitomized this realization and reaffirmed the collective commitment to changing the situation ${ }^{1}$. Presently, child labor is one of the chronic issues of children in the modern world.

\footnotetext{
* The author is a Post Graduate student in the Department of Economics at Concordia University, Montreal, Canada.

${ }^{1}$ The International Labor Organization brings together governments and workers' and employers' organizations to formulate international policies and programs that promote basic human rights at work, improve working and living conditions while enhancing
} 
The complex issue of child labor is a developmental issue worth investigating. The notion that children are being exploited and forced into labor, while not receiving education crucial to development, concerns many people. Child labor is most prevalent in the developing regions. In absolute term, it is Asia, as the most densely populated region of the world, which has the most child workers (probably over half) ${ }^{2}$. Pakistan is also faced with the problem of child labor. According to the ILO, there are between 19 to 20 million working children in Pakistan. Many households depend on child labor for survival. While reliable statistics are not available, it is thought that about two thirds of the child population work in services, manufacturing, fishery, agriculture and forestry. Despite legal prohibitions, industrial child labor is widespread, especially in textile factories and home-based production. By conservative estimates, one million children work as carpet weavers alone.

To eliminate child labor, Kerala State in India is an excellent example for developing countries. The Kerala government is spending more on education than any other state government in India. The spending on education was 36 per cent of the GDP of the state revenues. Due to the high level of education, Kerala produces a high quality skilled labor force and the government has made no special effort to end child labor. It is the result of the school system rather than the enforcement of labor legislations that has reduced the amount of child labor. ${ }^{3}$ The situation is different in Pakistan. The irrelevant and often inaccessible

employment opportunities and enterprise creation.

It establishes and supervises international labor standards, provides technical cooperation as well as training, education, research and publishing to support these efforts. It promotes decent and productive work for all. The ILO is 80 years old and pre-dates the founding of the United Nations.

The ILO decision-making bodies are made up of governments, employer and worker delegates from each member State. Its Governing Body is composed of 28 governments, 14 worker members and 14 employer members. It is the only tripartite institution in the multilateral system.

By ratifying an ILO Convention, a country becomes bound under international law to give effect to its provisions in national law and practice. The ILO has a procedure to supervise the application of ratified Conventions. It is based on regular reporting, independent input from the employers' and workers' organizations, on objective evaluation by independent experts and on examination of cases by the Organization's tripartite bodies.

2 According to the definition of International Labor Organization (ILO) child labor is work done by children under fifteen. Exception is made of work done by children with their parents at home in so far as aid in the latter's work is concerned and the child is not deprived of the possibility of going to school.

${ }^{3}$ Weiner M. 1991. The Child and the State in India. 
education system has led to an increase in child labor. In 1996, Carol Bellamy, Director of the United Nations Children's Fund, released the annual State of the World's Children report citing education as the single most important step in ending child labor. Bellamy's report went steadily further saying that with innovative programs which, for example, may pay families a small stipend to make up for the lost wages of children, developing nations can burnish their future prospects while rescuing today's children. That should be a focus of foreign aid as well. Provisions were made in the Pakistan Constitution to allow for the education of Pakistan's youth. Although these provisions were made, many children still find themselves illiterate, uneducated, and driven to work.

Mostly it is said that poverty and financial deprivation are reasons for sending small children to work under rigoros and hazardous conditions. But what forces the factory owners to employ child labor which is a clear violation of the national law and the constitution and the UN declaration of the rights of the child? It cannot only be because they are caring for poor and helpless families. It has to do with the availability of cheap and obedient labor who will not ask for raise in salaries or less working hours, not even protection of social security allowed by the law. The intention is quite clear. It is to make larger and larger profits but at the cost of the future generation of the nation.

A family's economic poverty may force the parents to engage their children in the labor market in lieu of schooling. Furthermore, sending children to school may be considered less critical, especially in settings where education appears to have no immediate benefits to parents and encouraging children to begin working could provide immediate economic relief to the family. In some situations, inconvenience or inaccessibility may also deter parents from sending their children to school, leading them to enter the labor force as a result.

An understanding of the key issues of child labor is necessary for the formation of effective policies in reducing and eventually eliminating child 1abor. This view underlines the many econometric analyses of child labor on micro data sets of developing countries. These studies had, earlier, mostly involved Latin American data on child labor, but recently they have extended to data sets of African and Asian countries. Examples include studies of Psacharopoulos (1997), Cartwright and Patrinos (1998) on Bolivian data, Grootaert (1998) on Cote d'Ivoire, Tienda (1979), Boyden (1988, 1991), Patrinos and Psacharopoulos (1997) on Peru, Psacharopoulos (1997) on Venezuela, Salazar (1988) on Colombia, Patrinos and Psacharopoulos (1995) on Paraguay, Jensen and Nielsen (1997) on Zambia, Addison et al 
(1997) on Pakistan and Ghana, Chaudhuri (1997) on India and Ray (1998) on Pakistani and Peruvian data. Child labor is still a cause for concern, for two reasons: first, because of the number of children affected, which is still very high; second, and most importantly, because of the negative repercussions that starting working life too young has on the personal development of children, as a result of the poor conditions in which it often takes place, and on the economic and social development of the country concerned.

In the last decade, the Pakistan National Assembly enacted two labor laws meant to curb such practices. The first, The Employment of Children Act of 1991, prohibited the use of child labor in hazardous occupations and environments. The second, The Bonded Labor Act of 1992, abolished indentured servitude and the peshgi system. As progressive as these laws were, the government failed to provide for their implementation and enforcement. It also neglected to inform the millions of working children and indentured servants that they were free and released from their debts. "We prefer to leave enforcement to the discretion of the police", says a Ministry of Labor official. "They understand best the needs of their community. Law is not an absolute. We must expect certain flexibility on the part of those who enforce it. Could this sometimes mean looking the other way? Absolutely."

A fundamental factor in the issue of Pakistan child labor rests in the inefficiency of protective legislation for working children. Although the government has made attempts to eradicate child labor, these provisions are greatly ignored and the industry continues. One problem with this legislation is that much of it fails to completely define the term child labor. Another complication lies within the country's vast population as their ignorance of the law and illiteracy prevent the enforcement of such proposals. This ignorance could be prevented through the establishment of a universal Pakistan dialect and a higher standard of education throughout the countryside.

This study focuses on child labor in Pakistan with two main objectives. We first estimate the prevalence of child labor in the 100 districts of Pakistan and then examine the hypothesis that child labor is significantly higher in districts that have a higher incidence of poverty and lower level of educational attainment.

The remainder of this paper is as follow: Section II describes the variables and data sources. The methodological issues are discussed in Section III. Section IV, gives the empirical results. The main conclusions are summarized in Section V. 


\section{Variable Description and Data Sources}

Data from the 1998 census of Pakistan was used to estimate the prevalence of child labor in the country's 100 districts. $^{4}$ The census collected data on child labor among children 10-14 year old.

Child Labor Rate: Child labor refers to the percentage of children gainfully employed (for remuneration in cash or kind) among all children 10-14 years old at the time of the census. The child labor force consists mainly of unpaid family workers. Although it is a common practice everywhere, child labor in family enterprises is more prevalent in rural than in urban areas. Likewise, children employed as wage-earners usually account for a relatively small percentage of total child labor. Child wage-earners are to be found more often in urban than in rural areas; moreover, the older the children, the more likely they are to be in this category.

Per Capita Income: In the present analysis, we will use per capita agriculture and manufacturing production of each district as an income proxy. Household income and wealth is the most discussed welfare attribute in the literature. Direct income data at provincial or district levels are not available; therefore various proxies are used to estimate the income and wealth position of a district. For the rural economy, cash value of agricultural produce per rural person and livestock per rural capita (LIVESTOCK) are used. All major and minor crops are considered to estimate the district's cash value from agriculture. This indicator is based on aggregation by assigning weights as recommended by the FAO (Pasha and Hassan, 1982) to reflect the capital value of various animals and poultry. For the urban part of a district, per capita value added in large-scale manufacturing (MANUFACTURING) is used to proxy the level of urban income. Value added by the small-scale component could not be included due to lack of data.

Literacy Rate: Data on literacy come from the 1998 census. Child literacy refers to the percentage of those who can at least read, write and do simple counts among all children 5-14 years old at the time of the census. Adult literacy refers to the percentage of adults who can at least read, write and count among all adults, i.e. those 15 years old and older.

Educational level is an indicator not only of those economically active in agriculture but those knowledgeable about it. It is assumed that

\footnotetext{
${ }^{4}$ Actually, Karachi consists of five districts but in this analysis, it is used as one district. Umer Kot district is also merged in Tharparker district.
} 
those with a longer period of education are more adjustable to new technologies and are able to experiment with new methods of farming compared to those with limited education or none at all. This is not to mention that higher educational standards could mean a good wage employment which can provide money for investment in the farm e.g. hire labor and buy inputs.

Deprivation Index: The Index of Multiple Deprivation (IMD) is based on the premise that deprivation is composed of multiple dimensions. These dimensions or sectors reflect different aspects of deprivations. Each sector is made up of a number of indicators. The selection of indicators is based entirely on the data available in the Population and Housing Census of 1998. The following indicators from four dimensions are used to compute district-wise indices of multiple deprivation: (a) Out of school male and female children aged 5-9: (b) Inadequate Housing structure and percentage of homeless population: (c) Residential housing services and (d) Unemployment rate.'

Household Size: We hypothetically assume that the larger the household, the more likely it is to be poor. One of the most important reasons put forward by especially the urban children for engaging in economic activity is to supplement household income. Rural children cited helping out in household economic enterprise as an equally important factor leading them to engage in market work.

\section{Methodology}

The main techniques of data analysis used are simple correlation coefficients and linear multiple regression. The unit of analysis is the district, not individuals, in this sense, it is "ecological" research. The lack of reliable and comparable statistical series on child labor at the national level means that it is impossible to study the trend of child labor over time. The following models are used for male and female child labor force analysis at the national level.

Equation No. 1

ChildLB $=\beta_{\mathrm{o}}+\beta_{1}$ Lit10 $\beta_{2}$ PCINM $+\beta_{3}$ Household $+\varepsilon$ ${ }^{5}$ The detailed methodology of the Multiple Deprivation Index is available in the
Appendix. 
Equation No. 2

ChildLB $=\beta_{0}+\beta_{1}$ Lit $15+\beta_{2}$ PCINM $+\beta_{3}$ Household $+\varepsilon$

Equation No. 3

ChildLB $=\beta_{\mathrm{o}}+\beta_{1}$ Lit10 $+\beta_{2}$ Dep_Index $++\beta_{3}$ Household $+\varepsilon$

Equation No. 4

ChildLB $=\beta_{\mathrm{o}}+\beta_{1}$ Lit10 $+\beta_{2}$ Dep_Index $++\beta_{3}$ Household $+\varepsilon$

Where

ChildLB $=$ Child Labor as percentage of total population aged 10-14 years.

Lit $10=$ Literacy Rate population aged 10-14 years.

Lit15 = Literacy Rate population aged 15+ years.

PCINM = Per capita income of each district (Agricultural + Manufacturing).

Dep_index $=$ Deprivation Index of each District.

Household $=$ Household size of each district

\section{Empirical Analysis}

Table-1 presents the descriptive statistics of all variables, which are used in this study. This table shows that 23.8 percent male children are involved in child labor. On the other hand, the share of the female labor force is only 1.4 percent. The results explain that child labor is purely a male child phenomena. The census data has not enough information about other aspects of child labor, and this makes it difficult to identify the children engaged in physically, intellectually or emotionally injurious work or conditions, and to target protection for them. Official statistics contain very limited data in these types of studies and reports of varying quality and objectivity. 
Table-1: Descriptive Statistics

\begin{tabular}{lrrrrr}
\hline Variables & \multicolumn{1}{c}{ Mean } & Median & Std. Dev. & Maximum & Minimum \\
\hline LFM1014 & 23.804 & 17.952 & 17.843 & 75.444 & 3.706 \\
LITM1014 & 53.148 & 53.989 & 18.830 & 88.203 & 12.282 \\
LITM15+ & 44.552 & 46.110 & 14.992 & 80.044 & 15.137 \\
LFF1014 & 1.386 & 0.856 & 1.614 & 8.904 & 0.060 \\
LITF1014 & 35.169 & 35.638 & 19.231 & 81.795 & 4.638 \\
LITF15+ & 17.825 & 15.177 & 12.713 & 60.450 & 2.391 \\
PCINM & 4227.115 & 3958.425 & 2405.068 & 14965.00 & 229.990 \\
Dep_Index & 64.814 & 65.655 & 10.845 & 89.060 & 24.590 \\
Household & 6.840 & 6.780 & 1.061 & 9.840 & 4.970 \\
\hline
\end{tabular}

Table-2 shows simple correlation among the variables which are used in this study. The correlation results clearly indicate that education has a negative relationship with child labor, both male and female. Per capita Income shows a non-relationship with male child labor, but it has a negative relationship with female child labor. On the other hand, district Deprivation Index has a strong positive relationship with male child labor.

Table-2: Correlation among variables

\begin{tabular}{lccccccccc}
\hline Variables & (A) & (B) & (C) & (D) & (E) & (F) & (G) & (H) & (I) \\
\hline LFM1014 (A) & 1.000 & & & & & & & & \\
LITM1014(B) & -0.822 & 1.000 & & & & & & & \\
LITM15+(C) & -0.787 & 0.959 & 1.000 & & & & & & \\
LFF1014 (D) & 0.286 & -0.382 & -0.361 & 1.000 & & & & & \\
LITF1014(E) & -0.629 & 0.880 & 0.912 & 0.278 & 1.000 & & & & \\
LITF15+(F) & -0.515 & 0.745 & 0.839 & -0.240 & 0.944 & 1.000 & & & \\
PCINM (G) & 0.007 & 0.007 & 0.021 & -0.115 & 0.048 & 0.022 & 1.000 & & \\
Dep_Index(H) & 0.669 & -0.806 & -0.873 & 0.257 & -0.881 & -0.914 & -0.050 & 1.000 & \\
Household (I) & -0.214 & 0.150 & 0.091 & -0.314 & -0.101 & -0.118 & -0.259 & -0.028 & 1.000 \\
\hline
\end{tabular}

Table-3 shows the results of linear multiple regression analysis in which literacy rate aged 10-14 years, literacy rate aged 15+ years, per capita income, Deprivation Index and household size are used as independent variables. The 
signs of all the variables are according to the expectation in all equations. Equation-1 illustrates a negative relationship between child labor and literacy rate of children aged 10-14 years. Per capita income of the district has a negative relationship with child labor and is not significant. The other variable household size has a strong positive relationship with child labor. In equation2 , the literacy rate of age 15 and above has a strong negative relationship with child labor. It is confirmed that increasing education of adults has a negative impact on child labor. The other two variables have the same trend in this equation. In equations 3 and 4, we drop the per capita income and include 'Deprivation Index' of the district. The Deprivation Index is insignificant in these equations which shows that child labor is not only a deprived district phenomena but it also exists in the well developed districts. If one extends Basu and Van's (1998) prediction that a household will not send its children to school if it falls into poverty, then a negative and statistically significant sign of the poverty variable has provided confirmation of their result. As in the case of child labor and, hence, consistent with the earlier results, the evidence on child labor confirms it. This provides confirmation of our earlier observation, also noted by Weiner (1996) that South Asian children, especially girls from poor districts, drop out of school to enter the labor market.

Table-3: Dependent Variable: Percentage of Male Child Labor Force 10-14 year aged

\begin{tabular}{lcccc}
\hline & Equation-1 & Equation-2 & Equation-3 & Equation-4 \\
\hline Constant & 32.897 & 45.245 & 12.127 & 31.266 \\
& $(1.796)$ & $(2.271)$ & $(0.895)$ & $(1.664)$ \\
Literate 10-14 years & -0.622 & & 0.540 & \\
& $(10.688)$ & & $(6.611)$ & \\
Literate 15 + years & & -0.756 & & -0.744 \\
& & $(9.610)$ & & $(5.257)$ \\
Log Per Capita Income & -0.583 & -1.457 & & \\
& $(0.307)$ & $(0.711)$ & & \\
Household Size & 4.333 & 3.760 & 4.535 & 3.855 \\
& $(3.618)$ & $(2.940)$ & $(3.861)$ & $(2.983)$ \\
Depreciation Index & & & 0.163 & 0.011 \\
& & & $(1.400)$ & $(0.070)$ \\
Adj-R & & & 0.71 & 0.65 \\
F-statistic & 0.70 & 0.65 & 0.90 & 30.53 \\
D-W Test & 38.71 & 31.33 & 40.90 & 1.72 \\
Mean Dependent Variable & 1.61 & 1.81 & 1.70 & 18.75 \\
\hline
\end{tabular}


The gender differential between sexes in Pakistan in respect of child labor is quite revealing with girls experiencing a much sharper reduction than boys in their schooling, when their households fall into poverty. Table4 explains the linear multiple regression results of female child labor. Equation-1 shows a negative significant relationship between child labor and literacy rate of girls aged 10-14 years. This relationship shows the importance of female education. The price of investment on female education can be very high. Previously, most free public education is in fact very expensive for a poor family, which is expected to meet the cost of books and other school supplies, uniforms and clothes, transportation, and sometimes even provide unofficial payment to teachers. The close complementarity between girls' and female wages, have an impact on child schooling. In other words, when female wages rise, the working mother tends to pull the daughter out of school and takes the child to work with her. It is also interesting to observe that girls in Pakistan, though not boys, experience significantly more schooling in urban areas than in the rural countryside.

Per capita income of the district has a strong negative relationship with female child labor. Poverty is the greatest single force which creates the flow of children into the workplace. It forces many children to work full time for their own and their families' survival. Furthermore, because of poverty, the acute need of many households to keep many family members working to ensure income security makes it nearly impossible for them to invest in their children's education. Experts have always pointed at poverty as the main reason for the escalating rate of drop-outs. Many of the children are forced into child labor to help their poor families earn supplementary incomes for food. Orphans, children from women-headed homes and destitutes fall easy prey to child labor. In rural areas, child labor is rampant because most children drop out of school due to shortage of food, because they are assigned to draw water from distant sources or because of inadequate health facilities.

Household size has shown a strong negative relationship with female child labor in this study. A large family size may have more male earners, which has a negative impact on the female child labor force. In equation-2, the literacy rate of age 15 and above has a strong negative relationship with female child labor. The other two variables have the same trend in this equation. In equations 3 and 4, we drop the variable per capita income and include Deprivation Index of the district. In these equations, the signs of all the variables are according to expectation. The Deprivation Index is insignificant in these equations which shows that female child labor is not only a deprived district phenomena but it also exists in the well developed 
districts. In order to overcome these obstacles, Pakistan must first recognize that a child labor crisis exists and then address each of its sources individually. Someone must be willing to accept responsibility for this injustice if it is to be eradicated.

Table-4: Dependent Variable: Percentage of Female Child Labor Force aged 10-14 year

\begin{tabular}{lcccc}
\hline & Equation-1 & Equation-2 & Equation-3 & Equation-4 \\
\hline Constant & 19.440 & 19.071 & 5.16 & 3.818 \\
& $(4.924)$ & $(4.783)$ & $(1.290)$ & $(0.744)$ \\
Literate 10-14 year & -0.034 & & 0.026 & \\
& $(3.153)$ & & $(1.010)$ & \\
Literate 15+year & & -0.043 & & -0.021 \\
& & $(2.930)$ & & $(0.405)$ \\
Log Per Capita Income & -1.573 & -1.580 & & \\
& $(3.816)$ & $(3.780)$ & & \\
Household Size & -0.530 & -0.533 & -0.457 & -0.447 \\
& $(2.034)$ & $(2.013)$ & $(1.534)$ & $(1.562)$ \\
Depreciation Index & & & 0.070 & 0.021 \\
& & & $(0.160)$ & $(0.324)$ \\
Adj-R & & & & \\
F-statistic & 0.38 & 0.37 & 0.14 & 0.13 \\
D-W Test & 9.56 & 8.95 & 3.58 & 3.24 \\
Mean Dependent Variable & 1.46 & 1.46 & 1.46 & 18.75 \\
\hline
\end{tabular}

The results of the equations suggest that a two-pronged policy intervention is needed: To raise their income which would make simultaneous efforts to increase literacy. Literacy will have an influence in reducing male and female child labor. Improvements in schooling would both discourage child labor and significantly improve the human development index. For example, poverty may be clustered in certain groups of people differentiated by ethnicity or other classifications. The results also suggest that there are different underlying socioeconomic conditions affecting the prevalence of male and female child labor.

The state of education in Pakistan also needs to be improved. High illiteracy and dropout rates are reflective of the inadequacy of the educational system. Poverty plays a role in the ineffectiveness of the educational system. Dropout rates are high because children are forced to 
work in order to support their families. The attitudes of the people also contribute to the lack of enrolment - parents usually feel that work develops skills that can be used to earn an income, while education does not help in this matter. Compulsory education may help in regard to these attitudes. The example of Sri Lanka shows that compulsory education has worked in those areas. There are many socioeconomic differences between Sri Lanka and Pakistan. What types of social welfare structure do these places have? What are the attitudes of the people? Is there some other reason why the labor market for child laborers is poor in these areas? These are some questions that need to be answered before applying the concept of compulsory education to Pakistan. Hopefully the future will show that this action has made progress towards universal education, and eradicating child labor.

Child labor cannot be eliminated by focusing on one determinant, for example education, or by brute enforcement of child labor laws. The government of Pakistan must ensure that the needs of the poor are fulfilled before attacking child labor. If poverty is addressed, the need for child labor will automatically diminish. No matter how hard Pakistan tries, child labor always will exist until the need for it is removed. The development of Pakistan as a nation is being hampered by child labor. Children are growing up illiterate because they have been working and not attending school. A cycle of poverty is formed and the need for child labor is reborn after every generation. Pakistan needs to address the situation by tackling the underlying causes of child labor through governmental policies and the enforcement of these policies. Only then will Pakistan succeed in the fight against child labor. 


\section{Appendix}

\section{Definition and Methodology of Index of Multiple Deprivation (IMD)}

The Index of Multiple Deprivation (IMD) is based on the premise that deprivation is composed of multiple dimensions. These dimensions or sectors reflect different aspects of deprivations. Each sector is made up of a number of indicators. The selection of indicators is based entirely on the data available in the Population and Housing Census of 1998. The following indicators from four dimensions arc used to compute district-wise indices of multiple deprivation.

\section{Education}

Out of School Children - Male [Male children aged 5 to 9 years, not attending school]

Out of School Children - Female [Female children aged 5 to 9 years, not attending school]

Iliteracy Rate - Male [Percentage of illiterate males among the male population aged 10 years and above]

Iliteracy Rate - Female [Percentage of illiterate females among the male population aged 10 years and above]

\section{Housing Quality and Congestion}

Inadequate Wall Structure [Housing with walls of un-baked bricks, earth bound, wood or bamboo material]

Inadequate Roofing [Houses with un-baked bricks, earth bound, wood or bamboo used in roofing]

Index of Overcrowded Housing [Person per rooms standardized with (Actual1.5)/(Maximum- $1.5 * 100]$

Housing Units with One Room [Percentage of houses reporting only one room in the house]

Percentage of Homeless Population [Population with no shelter]

Percentage of Non-Owners' Households [Rented or rent free houses]

Percentage of Households with No Facility of

- Separate Kitchen

- Bathroom

- Latrine 


\section{Residential Housing Services}

Un-electrified Households [Percentage of Households having no electricity connection]

Households not using Cooking Gas [Households using wood or kerosene oil as cooking fuel]

\section{Housing with no Inside Piped Water Connection}

\section{Employment}

Unemployment Index [Unemployment rate is referred to as a percentage of the population aged a 15 to 65 , not working and looking for work] standardized with (unemployment rate/maximum unemployment* 100)

Index of Non-Manufacturing Employment [Share of non-manufacturing employment in total employed labor force] standardized with (share /maximum share* 100).

The methodology used for constructing the Deprivation Indices is as follow. Given that all the above indicators are used in terms of 'percentages of the population affected by the type of deprivation', they can be easily combined. Therefore, deprivation indicators in each sector are first combined to create the four Sectoral Indices.

The indicators can be combined by assigning them equal weight. This would, however, not take account of the relative importance of the different indicators in sectoral deprivation. As such, the Principal Component Technique of Factor Analysis is used to generate weights. This statistical procedure assigns the highest weight to those variables that have the greatest variance (or dispersion); indicators with the lowest level of inequality are assigned the lowest weight. After assigning these weights, sectoral indices are computed and then ranked in order to compare deprivation levels across districts and provinces.

Once sectoral indices have been calculated, an overall index of multiple deprivations is derived. Having considered various options for computing the overall index, it has been decided to employ the criteria used by the UNDP for deriving their Human Poverty Index (HPI). The following formula is used to derive the Index of Multiple Deprivation.

$\left.I M D=\left[1 / 4^{\mathrm{a}}\{(E)\}^{\mathrm{a}}+\{H Q)^{\mathrm{a}}+(H S)^{\mathrm{a}}+(L)^{a}\right\}\right]^{1 / \mathrm{a}}$ 
Where

$\mathrm{IMD}=$ Index of Multiple Deprivation

$\mathrm{E}=$ Index of Education Deprivation

$\mathrm{HQ}=$ Index of Deprivation in Housing Quality

$\mathrm{HS}=$ Index of Deprivation in Housing Services

$\mathrm{L}=$ Index of Deprivation in Employment

$\forall=3$

The value of $\forall$ has an important impact on the value of the Index. If $\forall=1$, the IMD is the average of its four sectors. As $\forall$ rises, greater weight is assigned to the sector in which there is the most deprivation. Following UNDP, the value of $\forall$ is set at 3 to give additional but not overwhelming weight to the area of greater deprivation. 


\section{References}

Addison, T., Bhalotra, S., F. Coulter and C. Heady 1997, Child Labor in Pakistan and Ghana: A Comparative Study, mimeo. Centre for Development Studies, University of Bath, UK.

Alderman, Harold, Peter F. Orazem and Elizabeth M. Patemo 1996, "School Qaulity, School Cost and the Public/Private School Choices of LowIncome Households in Pakistan", The World Bank: Impact Evaluation of Education Working Paper Series No. 2.

Basu, K. and P.H. Van 1998, "The Economics of Child Labor", American Economic Review, 88(3), pp412-427.

Blackwood, D.L. and R.G. Lynch 1994, "The Measurement of Inequality and Poverty: a Policymaker's guide to the literature”, World Development 22 (4) pp567-578.

Borooah, Vani K 2000, "The Welfare of Children in Central India: Econometric Analysis and Policy Simulation”, Oxford-DevelopmentStudies 28(3), October 2000.

Cartwright, K and H.A. Patrinos 1998, "Child Labor in Urban Bolivia” in C. Grootaert and H. Patrinos (eds), The Policy Analysis of Child Labor: A Comparative Study'Mimeo: World Bank, Washington.

Chaudhuri, D.P. 1997, "A Policy perspective on Child Labor in India with Pervasive Gender and Urban Bias in School Education”, Indian Journal of Labor Economics, 40(4), pp789-808.

Ghayur Sabur 1996, "Labor Market Issues in Pakistan: Unemployment, Working Conditions,a nd Child Labor”, Pakistan Development Review 35(4) pp 789-803

Glewwe, Paul and Jacques Van der Gaag 1990, "Identifying the poor in developing countries: do definitions matter?”. World Development 18(6) pp803-814.

Grootaert, C. 1998, "Child Labor in Cote d'lvoire: Incidence and Determinants" in C. Grootaert and H. Patrinos (eds), The Policy Analysis of Child Labor: A Comparative Study'Mimeo: World Bank, Washington. 
Hyder S. Nazre 1998, "Child Labor in Pakistan: Problems, Policies and Programmes”, Asia-Pacific Development Journal 5(1), pp 121-32.

ILO 1996, Economically Active Populations: Estimates and Projections, 1950-2010, International Labor Organization, Geneva.

Jacob, Hanan G. and Emmanuel Skouflas 1997, "Risk, Financial Markets, and Human Capital in a Developing Country”, Review of Economic Studies 64 (July): pp 311-335.

Jari S.M. Younus and Raishad 1997, "Sonic Dimensions of Child Labor in Pakistan”, Pakistan Development Review 36(1) pp69-86.

Jensen, P. and H.S. Nielsen 1997, "Child labor or School Attendance? Evidence form Zambia”, Journal of Population Economics, 10(4) pp 407-424.

Mehra-Kerpelman, K. 1996, “Children at Work: How Many and Where?" World of Work 15 :pp8-9

Patrinos, H.A. and Psacharopoulos,G. 1995, "Educational Performance and Child Labor in Paraguay", International Journal of Educational Development, 15(1) pp 47-60.

Patrinos, H.A. and Psacharopoulos, G. 1997, "Family Size, Schooling and Child Labor in Peru: An Empirical Analysis", Journal of Population Economics, 10(4), pp 377-386.

Psacharopoulos, G. 1997, "Child Labor Versus Education Attainment: Some Evidence for Latin America”, Journal of Population Economics, 10(4), pp 377-386.

Ravallion, Martin and Quentin Wodon 2000, "Does Child Labor Displace Schooling? Evidence on Behavioral Responses to an Enrollment Subsidy”, Economic Journal, Vol. 110, March 2000, pp 158-176.

Ray, R. 1998, "Analysis of Child Labor in Peru and Pakistan: A Comparative Study”, mimeographed. School of Economics, University of Tasmania.

Ray Ranjan 2000, "Analysis of Child Labor in Peru and Pakistan: A Comparative Study”, Journal of Population Economics 13(1) pp 3-19. 
Salazar M.C. 1988, "Child Labor in Colombia: Bogota's Quarries and Brickyards”, in A. Bequele and J. Boyden (eds), Combating Child Labor, ILO, Geneva.

Thapa Shyam, Chhetry Devendra and Aryal Ram H. 1996, "Poverty, Literacy and Child Labor in Nepal: A District-level Analysis”, Asia-Pacific Population Journal 11(3), pp3-14

Tienda, M. 1979, "Economic Activity of Children in Peru: Labor Force Behaviour in Rural and Urban Contexts”, Rural Sociology, 44(2), pp 370-391.

Weiner, M. 1991, The Child and the State in India. Princeton: Princeton University Press. 